\title{
THE URGENCY AND IMPLICATION OF BREAST MILK DONOR IN INDONESIA IN MASHLAHAH PERSPECTIVE
}

\author{
Khotifatul Defi Nofitasari \\ Faculty of Sharia, Ponorogo State Islamic Institute \\ J. Puspita Jaya, Krajan, Pintu, Kec. Jenangan, Kabupaten Ponorogo, Jawa Timur 63492 \\ Email: Devimaulana007@gmail.com
}

\begin{abstract}
In Islamic teachings, the issue of breastfeeding is a very important issue to pay attention to, because it can have an impact on the issue of the prohibition of marriage and lineage. The purpose of this study is to dig deeper into the urgency of breastfeeding donors and their implications based on the practice of breastfeeding donors in Indonesia, and a review of the mashlahah of these breast milk donors. This type of research is library research, with analytical descriptive method. This research uses mashlahah theory with ushul fiqh approach. As a result, breast milk donation in Indonesia can be done by fulfilling several conditions: first, the request of the biological mother or the baby's family. Second, the identity, religion, and address of the breast milk donor are clearly known by the mother or family of the baby receiving the donor. Third, the approval of the breast milk donor by knowing the identity of the donor recipient baby. Fourth, the breast milk donor is in good health and has no medical indication. Fifth, breast milk is not traded. Meanwhile, based on Ijtihâd istishlâhî, breast milk donation which aims to help babies who do not get breast milk from their biological mothers for certain reasons, is a humanitarian aid to save human life. Therefore, it is legally permissible to donate breast milk and can be categorized as mashlahah dharuriyat if the mother of the baby is sick and the baby is premature or sick. Including mashlahah hajiyat if the baby's mother dies, or her whereabouts are not known..
\end{abstract}

Keyword: Breastfeeding Donations; Mashlahah, Islamic Law

Abstrak: Dalam ajaran Islam, masalah persusuan adalah masalah yang sangat penting untuk diperhatikan, karena dapat berdampak pada masalah pengharaman pernikahan dan nasab. Tujuan penelitian ini untuk menggali lebih dalam urgensi donor air susu ibu (ASI) dan implikasinya berdasarkan praktek donor ASI di Indonesia, serta tinjauan mashlahah terhadap donor ASI tersebut. Jenis penelitian ini adalah penelitian pustaka, dengan metode deskriptif analitik. Penelitian ini menggunakan teori mashlahah dengan pendekatan Ushul al-Fiqh. Hasilnya, donor ASI di Indonesia dapat dilakukan dengan memenuhi beberapa syarat: pertama, permintaan ibu kandung atau keluarga bayi yang bersangkutan. Kedua, identitas, agama, dan alamat pendonor ASI diketahui dengan jelas oleh ibu atau keluarga dari bayi penerima donor. Ketiga, persetujuan pendonor ASI dengan mengetahui identitas bayi penerima donor. Keempat, pendonor ASI dalam keadaan sehat dan tidak mempunyai indikasi medis. Kelima, ASI tidak diperjualbelikan. Sedangkan berdasarkan Ijtihâd istishlâhî, donor ASI yang bertujuan untuk membantu bayi yang tidak mendapatkan ASI dari ibu kandungnya karena hal tertentu, merupakan bantuan kemanusiaan untuk menyelamatkan kehidupan manusia. Oleh sebab itu, donor ASI hukumnya mubah dan bisa dikategorikan dalam mashlahah dharuriyat jika ibu si bayi dalam keadaan sakit dan bayi dalam keadaan premature atau sakit. Termasuk mashla $\underline{h}$ ah hajiyat jika ibu si bayi meninggal, atau tidak diketahui keberadaannya.

Kata kunci: Donor Air Susu Ibu; Mashlahah; Hukum Islam 


\section{Introduction}

Breastfeeding children for every mother by providing exclusive breast milk (hereinafter abbreviated as ASI) is a very important thing for human survival. However, not a few mothers are given the opportunity to be able to breastfeed their children for various reasons, such as medical reasons, the mother died, or indeed because they are busy outside the home (work). ${ }^{1}$ The Breast's milk Bank was first established in Vienna, Austria in 1909, while in 1919 there were two breast milk banks in Boston, America and in Germany. Awareness of the benefits of breastfeeding, so that more premature babies die in vain, has encouraged many other countries to establish ASI Banks. ${ }^{2}$ Countries that already have ASI Banks include: the United States, Australia, Brazil, Bulgaria, Denmark, Finland, Canada, France, Germany, Greece, India, England, Japan, China, Norway, Sweden, and Switzerland, and 1 ASI Bank. in Kuwait. In Indonesia, to establish an ASI Bank, there is still a lot of homework to be done. However, the practice of donating breast milk, such as that carried out in the ASI Bank, is mostly carried out by the people of Indonesia.

The phenomenon of breastfeeding donors is not something new to hear in Indonesia. The practice of donating breast milk is not only done in big hospitals, ${ }^{3}$ but also carried out in lactation clinics, as well as the Association of Breastfeeding Mothers in Indonesia. Breast

1 Tyas Pratama Puja Kusuma dan Dania Gusmi Rahayu, "Sistem Informasi Pengelola Bank ASI Berbasis Website (Studi Kasus: Posyandu Keluarahan Bantarsoka)", Jurnal Pendidikan Informatika, Vol. 5, No. 1, Juni tahun 2021, p. 2.

2 Nur liana, "Bank ASI Perspektif Hukum Islam", Jurnal Al-Himayah, Vol. 4, No. 1. Maret 2020, p. 3.

${ }^{3}$ Maratul Iqrami, "Donasi Bank ASI (Air Susu Ibu) di RSUD Dr. Soetomo Surabaya dalam Perspektif Hukum Islam", Tesis Universitas Islam Negeri Maulana Malik Ibrahim Malang, 2012. milk donors are also not only found among ordinary people, breast milk donors also occur among public figures. Several artists have also publicly stated in the media that they are carrying out breast milk donation activities.

In Islam, the issue of breastfeeding is a very important issue and needs to be considered. The problem of breastfeeding can have an impact on the problem of prohibiting marriage because it is like lineage. However, breast milk banks or breast milk donors are a new phenomenon for which there is no clear discussion in the Qur'an or Hadith. Therefore, there are pros and cons to the issue of breastfeeding donors among scholars, such as Wahbah Zuhaili who rejected the activity for fear of confusion and unclear lineage due to receiving breast milk from donors. ${ }^{4}$ On the other hand, Yusuf Qaradawi is one of the scholars who allow this activity, because the donor mother and donor baby do not breastfeed directly, so there is no change in mahram status. ${ }^{5}$

In Indonesia, religion plays an important role in people's lives. This is stated in the ideology of the Indonesian nation, namely the first precept: "God Almighty". According to the results of the last census conducted in 2010 it was found that $87.18 \%$ of the 237,641,326 Indonesian population embraced Islam. Indirectly, it can be concluded that the majority of Indonesia's population is Muslim. From this description, several epistemological questions emerge regarding the Indonesian ASI bank phenomenon, namely: What is the background for the emergence of breast milk donor activities in Indonesian society?

${ }^{4}$ Atika Nur Anisa, "Rekontekstualisasi Rada'ah di Era Digital (Studi Donor ASI di Lactashare)", Jurnal Tahkim IAIN Ambon, Vol XVII, No 1, Juni 2021, p. 21.

${ }^{5}$ Yûsuf Qarâdhâwî, Hadyûl Islam Fatawî Mu'àshirah, alih bahasa As'ad Yasin, (Jakarta: Gema Insani Press, 1996), p. 782. 
What about concerns about the impact of breastfeeding donors, especially on the mixing of lineages which has implications for the prohibition of marriage? Therefore, the author wants to examine more deeply about breastfeeding donors in Indonesia, both in practice and law, as well as the implications for marriage.

\section{Definition, Benefits, and Impacts of Donating Breast Milk}

Donors in the Big Indonesian Dictionary are donors or donors, ${ }^{6}$ Breast milk is an emulsion of fat in a protein solution, lactose and secreted organic salts ${ }^{7}$ by the two glands of the mother's breast, which are useful as the main food for the baby. ${ }^{8}$ The definition of a breast milk donor is a person who contributes breast milk to babies in need, as is the case with the definition of blood donation. The definition of breast milk donor is a woman who voluntarily gives her breast milk to help babies who need breast milk and do not get breast milk from their biological mother due to certain factors with the aim of saving the baby's life.

Breast's milk has advantages compared to other milk (formula milk), such as: carbohydrates that vary according to the baby's needs, low protein and very suitable because the protein elements can be completely absorbed by the baby, fat increases according to the baby's development, and complete vitamin and mineral content for the baby's needs.'

${ }^{6}$ Departemen Pendidikan dan Kebudayaan, Kamus Besar Bahasa Indonesia, (Jakarta: Balai Pustaka, 2005), p. 1058 .

${ }^{7}$ Sekresi adalah proses untuk membuat dan melepaskan subtansi kimiawi dalam bentuk lendir yang dilakukan oleh tubuh dan kelenjar.

${ }^{8}$ Rudi Haryono dan Sulis Setianingsih, Manfaat ASI Ekslusif Untuk Buah Hati Anda, (Yogyakarta: Goyen Publishing, 2014), p. 4.

${ }^{9}$ Atika Proverawati dan Siti Asfuah, Buku Ajar Gizi
The ingredients present in breast milk make it the most ideal and good food for babies. Breast milk can help start a good life for babies by increasing growth, increasing weight and reducing the risk of obesity. ${ }^{10}$ Breast milk also contains antibodies, so it can protect babies from disease, reducing the incidence of dental caries ${ }^{11}$ in infants, and increase intelligence so that babies can get a higher IQ than when babies consume formula milk. ${ }^{12}$

It is undeniable that breastfeeding donors also have a negative impact. The most important impact of donating breast milk is in terms of health. There are several diseases that can be transmitted through breast milk, such as Hepatitis B, Hepatitis C, HIV and Rubella. Therefore, it is necessary to have a serological examination or blood test to identify the disease. ${ }^{13}$ The second impact is the impact from a legal perspective, especially Islamic law. In Islamic law, there is one cause of mahram apart from lineage and marriage, namely breastfeeding. ${ }^{14}$ Therefore, it is very important that the identity of the donor and the donor's child is known for certain. To avoid confusion in the future. The third impact is the psychological impact, where children who are breastfed by their biological mothers have a closer inner relationship than children

Untuk Kebidanan, cet.ke-1, (Yogyakarta: Numed, 2009), p. 97-99.

10 Siti Rokhmatul Ummah, "Memahami Maqashid Asy-Syariah pada Ayat Radha'ah Perspektif Keadilan Gender", Jurnal Ilmiah Ahwal Syakhsiyyah, Vol. 3, No.1, 2021, p. 20.

${ }^{11}$ Dental caries is an infectious disease that damages the tooth structure causing cavities. Based on the definition of dental caries in Wikipedia, hppt://id.m.wikipedia.org/ wiki/karies_gigi

12 Dwi Sunar Prasetyo, Buku Pintar ASI Ekslusif: Pengenalan, Praktik dan Kemanfaat-kemanfaatannya, cet. ke-1, (Yogyakarta: DIVA Press, 2099), p. 77-78.

${ }^{13}$ Maratul Iqrami, "Donasi Bank ASI...”, p.78.

${ }^{14}$ Adil Abdul Mun'im Abu Abbas, Az-Zawaj Wa AlAlaqât Al-Jinsiyyah Fi Al-Islam, alih bahasa Gazi Said, (Jakarta: Al-Mahira, 2008), Cet. ke-2, p. 37. 
who are not breastfed by their biological mothers. ${ }^{15}$ However, in urgent circumstances, such as medical reasons, or breast milk of the biological mother is not possible in quality or quantity, donor breast milk is the best solution than giving children formula milk during the exclusive breastfeeding period.

\section{Breastfeeding Donor Practice in Indonesia}

In Indonesia, the existence of ASI banks is strongly supported by UNICEF and WHO. The due diligence process for Bank ASI requires sophisticated equipment, so Indonesia has to do a lot of homework first to get to that point. Carolus Lactation Clinic, has practiced like a breast milk bank, armed with literacy from overseas ASI banks and permission from 5 religious leaders. However, it only lasted 3 years. Nevertheless, the practice of donating breast milk is still widely practiced in the community.

As has been described in the background, that breastfeeding donors are not something new to hear in Indonesia. The practice of donating breast milk is not only carried out in big hospitals, one of which is done at RSUD Dr. Soetomo Surabaya, ${ }^{16}$ but also done in lactation clinics ${ }^{17}$ The Association of

${ }^{15}$ Mangku Sitapoe, ASI Eksekutif: Arti Penting Bagi Kehidupan, (Jakarta: PT.Indeks, 2013), Cet.ke-1, p. 45.

16 Dr. Soetomo Hospital Surabaya is a hospital that not only serves treatment, but also the highest teaching hospital, research and referral center in East Java. Dr Soetomo Hospital practices like an ASI Bank by carrying out various procedures such as contacting a lactation service center, filling out forms, interviewing and screening processes, medical examinations, donations, then the breast milk will undergo a pasteurization process to kill harmful bacteria. Maratul Iqrami, "Donation to the ASI Bank (Mother's Milk) at Dr. Soetomo Hospital. Surabaya in the Perspective of Islamic Law", Thesis of the State Islamic University of Maulana Malik Ibrahim Malang, 2012, p. 43

${ }^{17}$ One of the lactation clinics that accept breast milk donors in the Semolo Waru Utara area, No. 4 Surabaya. Interview with the midwife at the clinic, 17 September 2021.
Breastfeeding Mothers in Indonesia (AIMI) does a lot of donating breast milk, as in Yogyakarta on the Twitter account @AIMI_ Jogja, October 23, 2012, it was announced that 15 bottles of donor milk were available for babies in need. AIMI Jakarta also carries out the practice of donating breast milk, and many other exclusive breastfeeding communities provide donation information through various social media. ${ }^{18}$

Breast milk donation in hospitals or lactation clinics generally has the same procedure. First, contact a lactation center either at a lactation clinic or at a hospital lactation center. Second, fill out the form and identify yourself. ${ }^{19}$ This data facilitates the process of recording data on breast milk donors and to whom breast milk is given. Third, the interview and screening process with an oral examination in the form of questions about personal data and medical history. Fourth, health checks. Medical examinations are carried out to detect the presence of a dangerous virus. Screening is also carried out to ensure that the baby does not contract any diseases that may be suffered by the donor mother. Fifth, the process of donating after undergoing screening and being declared disease-free. Sixth, breast milk undergoes a pasteurization process to kill harmful bacteria and viruses. In order not to be mixed with other breast milk, breast milk is grouped according to the name of the donor and the date of donation. Breast milk is also stored in special containers and at a

${ }^{18}$ Instagram is one of the social media that very often shares information about breast milk donors. Only by searching the search using hashtags (breast milk donors and local names), there is a lot of information on mothers who want to donate breast milk, as well as mothers who ask for breast milk donors for their children. For example \#donorasijogja. Based on the author's search about breastfeeding donor activities on social media Instagram.

19 Filling in self-identity for breast milk donation is also regulated in PPRI No. 33 of 2012 Article 11 paragraph 2 point 2 . 
certain temperature to make it more durable and awake. ${ }^{20}$

There are so many mothers who donate their breast milk, Maya Djatirman is one of them. Maya is a mother who works as a lawyer, she donated her breast milk for 25 babies who need breast milk. Many babies receive virtual milk donors for a full 6 months. Maya Djatirman donates her breast milk because she has a very abundant milk production because she likes to eat fruit and exercise. ${ }^{21}$ Vera Veronica's mother, a dentist also donated her breast milk through the lactation clinic Carolous. ${ }^{22}$ There are many more examples of mothers doing breast milk donation activities in Indonesia. This information can be seen in studies on breast milk donors, lactation clinics, major hospitals and various digital information such as social media, television and newspapers.

Breast milk donors in Indonesia do not only exist among ordinary people, but also occur among public figures. The wife of the vice regent of Trenggalek (Cak Ipin) donates her breast milk to a beautiful baby girl who was found without an identity. ${ }^{23}$ Several artists have also publicly stated in the media that they are carrying out breast milk donation activities, such as: Sarwenda ${ }^{24}$, Tya Ariestya, ${ }^{25}$ and Donita. ${ }^{26}$

\footnotetext{
${ }^{20}$ Maratul Iqrami, "Donasi Bank ASI..., p. 45.

${ }^{21}$ Published by youtube account "Official Net News" on 23 January 2014.

${ }^{22}$ Published by Youtube account "Kompas.com" on 9 March 2017.

23 Direct interview with the Deputy Regent of Trenggalek published by the Youtube account "Bioz Media" on August 30, 2016.

${ }^{24}$ Published by Youtube account "Cumicumi" on 16 August 2015.

25 Tya Arestya donated her breast milk to the premature twins of Surya and Cynthia Lamusu. Published by Youtube Account "Cumicumi" on 22 November 2016.

${ }^{26}$ Published by youtube account "Net Entertainment News" on 27 October 2016.
}

In south Jakarta, there is an ASI Delivery service called "pong ASI Delivery" which is the first professional shuttle service specifically for breastfeeding in Indonesia. Pong ASI is located at Jalan Tebet Timur 2 no. 12 006/07, Tebet Timur, South Jakarta. This ASI delivery service has 4 main services: First, PAD or a subscription pick-up service. Provides many daily, weekly, monthly subscription options without a maximum limit of breast milk bottles. Second, IDA or breast milk donor info service. This service provides information on breastfeeding donors to every mother who needs breastfeeding assistance as a donor recipient and mothers who want to distribute breast milk as a donor mother free of charge. Third, JAG or free shuttle service. This service is specifically for underprivileged families. Fourth, TIA or Breastfeeding Service. This service is intended for those who need breast milk care. ${ }^{27}$

Pong ASI was founded 8 years ago and operates today with a wider reach. Pong ASI was established with the aim of assisting the government's program on exclusive breastfeeding. Not only connecting and delivering donor breast milk to donor recipient mothers, but pong ASI also delivers breast milk from biological mothers who are outside the home to their babies who are at home. Harin Silalahi is a mother as well as a career woman who subscribes to pong ASI to provide exclusive breastfeeding to her baby in the midst of her busy life as a career woman. ${ }^{28}$ One of the mothers who uses pong ASI services to find and receive donor breast milk is Indirasari Larasati. Indirasari has been receiving breast milk from donor mothers for 14 months through pong ASI. Pong ASI

\footnotetext{
${ }^{27}$ Based on the official Pong ASI Delivery blog. http:// pongasi.blogspot.com, accessed Monday 1 October 2018.

${ }_{28}$ Published by Youtube Account "Official NET News" on 7 November 2013.
} 
only provides information or an intermediary between donor mothers and mothers who need donor breast milk. Henceforth, the donor mother and the mother who received the donor will communicate directly. ${ }^{29}$

Thus, breast milk donors have a very noble goal, namely to help and provide life opportunities for babies who cannot receive breast milk from their biological mothers. Therefore, as a society, we should be wiser to accept or donate breast milk. In addition to the identity and clarity of the donor's breast milk, the quality and assurance of the safety of the breast milk is also very important to pay attention to. People should donate their breast milk through hospitals or lactation clinics by following existing procedures to ensure the quality of donor milk. This is very important to do in order to achieve the goals of the breast milk donor itself. Breast milk donation through agencies can minimize the baby's transmission of the disease to the donor's mother because before donating various health checks are carried out to detect dangerous diseases that can be transmitted through breast milk.

The role of the government is urgently needed to provide further education to the community, so that they can donate their breast milk according to the regulated procedure. If in a case a mother wants someone who is already known to be a mother to donate breast milk for her baby, then she can consult the medical team. Because health checks and detection of diseases that can be transmitted through breast milk, it is very important to do for the safety of the baby itself.

${ }^{29}$ Published by Youtube Account "KOMPAS TV" on 9 February 2018 on "Sapa Indonesia Akhir Pekan" TV Program.

\section{Pillars and Legal Consequences of Radha âh}

Breastfeeding in figh terms is called arradhâ which comes from the verb $r a-d h \hat{a}^{\prime} a$ yardhi'u-râdh'an which means to suckle or suckle (to the mother), while the isim fa' il of radha'âh is ar -radhi'u which means sucker or suckle. ${ }^{30}$

In terms of the pillars of radha'âh, scholars agree that there are three things that are the pillars: nursing mothers, breast milk and breast milk. ${ }^{31}$ Meanwhile, in order to achieve harmony, there are conditions that must be met first. First, the feeding number reaches 5 suction times. This number is based on the hadith of Aisha narrated by Muslim, Tirmidhi, Nasa'I and Ibn Majah. The hadith explains that in the Qur'an, breastfeeding is regulated which causes the status of the mahram to be 10 sucks, then it is corrected to 5 sucks until the Prophet SAW died. ${ }^{32}$

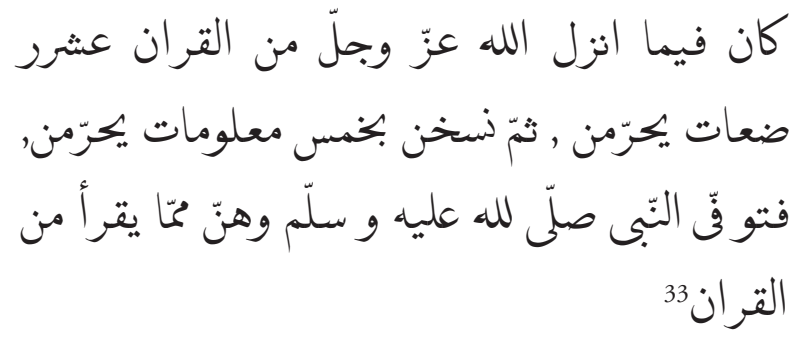

Second, the age of children receiving breastfeeding is a maximum of two years old (Al-Baqarah [2]: 233). Third, preparation can be direct or indirect. ${ }^{34}$

\footnotetext{
${ }^{30}$ Ahmad Warson Munawwir, Al-Munawwir Kamus Bahasa Arab Indonesia, (Surabaya: Progresif, 1997) p. 504-505.

${ }^{31}$ Mawardi, "Konsep Radha'ah dalam Fiqih", Jurnal Ilmu Syariah, Vol. 8, No. 1, Juni 2021, p. 10.

${ }^{32}$ Rifa'i dan Zuhri, Terjemahan Khulashah Kifayatul Akhyar, (Semarang: Karya Toha Putra, 1978), p. 240.

${ }^{33}$ Abî Dâwud Sulaiman ibn al-Asy'as Sajistâni, Sunan Abî Dâwud, (Al-Ardan: Dar al-A'lam, 2003), p. 331.

34 This opinion is the opinion of the majority of scholars, because what makes breastfeeding is the arrival of breast's milk to the baby's stomach. from the book of "Hukum Perkawinan Islam di Indonesia Antara Fikih Munakahat dan Undang-undang Perkawinan" Amir Syarifuddin, p. 118-119.
} 
Breastfeeding not to the biological mother has legal consequences or consequences, including the enactment of mahram status and the prohibition of marriage due to breastfeeding. Mahram because of milk is the same as mahram because of lineage.

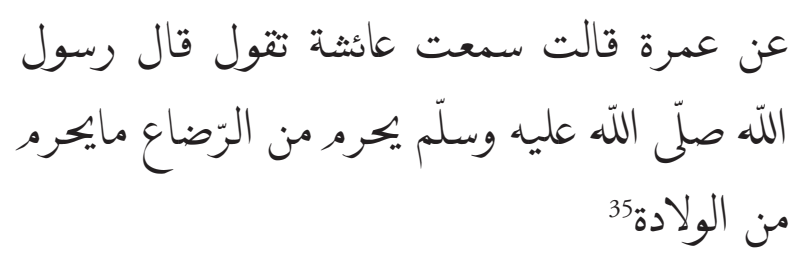

The Law of Donating Breast's milk in Indonesia

In Indonesia, exclusive breastfeeding for infants is a major concern of the government. Fulfillment of the baby's right to get exclusive breastfeeding is regulated in the Government Regulation of the Republic of Indonesia Number 33 of 2012 concerning Exclusive Breastfeeding. This Government Regulation is stipulated to support the implementation of the provisions of Article 129 paragraph (2) of Law No. 36 of 2009 concerning Health. ${ }^{36}$ The law on breastfeeding donors in PP No. 33 concerning exclusive breastfeeding is regulated in Article 11.

Biological mothers who cannot provide exclusive breastfeeding to their babies may use breast milk from donor mothers. ${ }^{37}$ Breast milk donation can be done by fulfilling several conditions: first, the request of the biological mother or the baby's family. Second, the identity, religion and address of the breast

35 Abî 'Abd al-Rahmân Ahmad Ibn Syi'aib al-Nasầi, Sunnah An-Nasầi, (Beirut: Dar Ihya' al Turath al-Arabi, tt), p. 561.

${ }^{36}$ Article 129 (1) The government is responsible for establishing policies in order to guarantee the right of infants to obtain policies in order to guarantee the rights of infants to obtain exclusive breastfeeding. (2 further provisions as referred to in paragraph (1) are regulated by government regulations. As seen from the Law of the Republic of Indonesia Number 36 Year 2009 concerning Health Pdf

${ }^{37}$ Article 11 paragraph 1, PPRI Number 33 of 2012 milk donor are clearly known by the mother or family of the donor baby. Third, the approval of the breast milk donor by knowing the identity of the baby who is the recipient of the donor. Fourth, the breast milk donor is in good health and has no medical indication. Fifth, breast milk is not traded. ${ }^{38}$ However, donation of breast milk must be carried out based on religious norms, socio-cultural aspects, quality and safety of breast milk. ${ }^{39}$

In the case of breastfeeding donors according to Islamic law in Indonesia, it has not been regulated at all, either in the Marriage Law No. 1 of 1974 or in the Compilation of Islamic Law. However, in 2013 the Fatwa Council of the Central Indonesian Ulema Council chaired by Prof. Dr. Hj. Hasanuddin AF, MA, sets a stance on breastfeeding donors. The Indonesian Ulema Council is a forum for deliberation of scholars, zu'ama, and Muslim scholars in Indonesia. ${ }^{40}$

The Indonesian Ulema Council is the most competent institution for solving and answering every socio-religious problem that always arises and is faced by the community. MUI is also an institution that has full trust, both from the community and from the government. ${ }^{41}$ Although the MUI Fatwa is not a binding positive law, the fatwa issued by the MUI is the most influential fatwa against Muslims in Indonesia.

In determining the fatwa for breastfeeding donors, MUI uses 4 sources of Islamic law, namely: the word of God in the Qur'an, ${ }^{42}$

${ }^{38}$ Article 11 paragraph 2

${ }^{39}$ Article 11 paragraph 3

${ }^{40}$ Ichwan Sam, Pedoman Penyelenggaraan Organisasi Majelis Ulama Indonesia, (Jakarta: MUI Pusat, 2001), p. 6-7.

${ }^{41}$ Decision of the Ijtima Ulama of the Indonesian Fatwa Commission regarding the Fatwa Guidelines for the Indonesian Ulema Council, Pdf.

42 The word of God which is the legal basis for determining the MUI fatwa regarding breastfeeding donors is Surah al-Baqarah verse 233, Surah an-Nisa verse 
mu'tabarah hadith of the prophet, ${ }^{43}$ Atsar Companions and some figh rules. MUI also pays attention to the opinions of previous madhhab scholars such as the opinion of Zaynuddin bin 'Abdul 'Aziz Al-Mâlibâri in the book Fath al-Mu'in, the opinion of AshSyîrazî in the book Al-Muhażżab, the opinion of Ibn Qudâmah in the book Al-Mughnî, the opinion of Muhammad Ibn al-Hasan in the Book of Al-Mabsîth, along with the opinions of other scholars as mentioned in the book of Al-Mughnî. This fatwa is also equipped with opinions, suggestions and inputs that developed in the Fatwa Commission session at the last fatwa commission meeting July 13, 2013. ${ }^{44}$

It is stipulated in this fatwa that a mother may give breast milk to a child who is not her biological child, and vice versa as long as it fulfills the syar'i needs. The condition of the donor mother is that she must be physically and mentally healthy, and not pregnant. Breast milk should not be commercialized or traded. However, donors may receive wages (ujrah) as childcare services, not as buying and selling breast milk. For the problem of the occurrence of mahram due to breastfeeding, MUI stipulates the conditions that must be met, namely: first, children who receive breastfeeding are a maximum of two years old qamariyah. Second, the full identity of the breastfeeding donor mother is known.

23, Surah al-Maidah verse 2, and Surah al-Mumtahanah verse 8

43 There are at least 5 hadiths of the Prophet that form the legal basis for the MUI fatwa on breastfeeding donors. Hadith about the age of breastfeeding history of Abu Daud, hadith history of Bukhari and also hadith history of Daaruquthni, hadith about the consequences of breastfeeding, narrated by Bukhari, and also hadith about breastfeeding numbers that cause Muslim history to be accepted. Based on the attachment of the MUI Fatwa regarding breast milk donors.

${ }^{44}$ Fatwa of the Indonesian Ulema Council Number 28 of 2013 concerning the Problem of Donating Breast's milk (Istirdha'), pdf.
Third, the amount of breast milk consumed is at least five puffs. Fourth, breastfeeding in any way directly or indirectly. Fifth, the breast milk consumed by the child is filling. ${ }^{45}$

\section{Sociological Analysis of Breast Milk Donor Activities in Indonesia.}

Law and society are two inseparable phenomena. Basically, law is a society or culture when viewed from a certain point of view. Therefore, the sociological approach to law occupies an important role for the legal system. ${ }^{46}$ Sociology of Law discusses the interrelationships between legal change and society. Changes in law can affect changes in society and vice versa, changes in society can cause changes in law. ${ }^{47}$ If this approach is applied in the study of Islamic law, the sociological influence of Islamic law can be seen in the influence of Islamic law on changes in Muslim society and the influence of Muslim society on the development of Islamic law.

1. The influence of Islamic law on societal change: as the maestro of Sociology Emile Durkheim introduced the social concept of religion. Change in society "social change" is defined as "the alteration of patterns of culture, social culture, and social behaviors overtime". In this form, Islamic studies understand how far people judge the good and bad of something based on religious teachings. For example, the prohibition of usury in Islamic teachings has an effect on the growth of Islamic banking.

2. The effect of societal change on the understanding and development of Islamic

${ }^{45}$ Fatwa of the Indonesian Ulema Council Number 28 of 2013 concerning the Problem of Donating Breast's milk (Istirdha'), pdf.

${ }^{46}$ Soerjono Soekanto, Pendekatan Sosiologi Terhadap Hukum, (Jakarta: Bina Aksara, 2008), p. 9.

${ }^{47}$ Sudirman Tebba, Sosiologi Hukum Islam, (Yogyakarta: UII Press Indonesia, 2003), p. 1 
law: this formulation reminds of the theory of rational choice of religion which is basically based on observations of Christian society in the West. For example, the geographical differences between Basrah and Egypt led to the birth of Qaul Qadm and Qaul Jadd for Imam Shafi'î. As a concrete example, the ulema's fatwa will be influenced by the socio-political environment, social structure and culture in which the ulema is located. The fatwa of ulama who are members of organizations close to the government will be different from the fatwas of independent scholars, because of the differences in the social structure they occupy. ${ }^{48}$

In Indonesia, public awareness about the importance of exclusive breastfeeding for babies as the main food is getting bigger. This happened after the government program regarding the obligation to provide exclusive breastfeeding for at least the first 6 months, ${ }^{49}$ so that people know more about the extraordinary benefits of breastfeeding for babies compared to other milks. Every health worker and the organization of health service facilities are required to provide information and education on exclusive breastfeeding to the mother or family members of the baby in question from the prenatal check-up until the period of exclusive breastfeeding. ${ }^{50}$

48 Mohammad Shodik, "Sosiologi Hukum Islam", Hand Out Fakultas Syari'ah dan Hukum Universitas Islam Negeri Sunan Kalijaga Yogyakarta, 2013, p. 171.

${ }^{49}$ Article 1 paragraph (2) of PPRI No.33 of 2012, "Exclusive Breast's milk, hereinafter referred to as Exclusive Breastfeeding, is breast milk that is given to a baby from birth for 6 (six) months, without adding or replacing it with other foods and drinks". Article 6 of PPRI No.33 of 2012 "every mother who gives birth must give exclusive breastfeeding to the baby who is born".

${ }^{50}$ Article 13 paragraph (1) of the 2012 PPRI, "In order to achieve optimal utilization of exclusive breastfeeding, Health Workers and providers of Health Service Facilities are required to provide information and education on exclusive breastfeeding to mothers and/or families of the babies concerned from the pregnancy check-up until the
In this Government Regulation on exclusive breastfeeding, there are also regulations and conditions for donating breast milk, for babies who cannot get breast milk from their biological mothers. The large number of babies who cannot get breast milk from their biological mothers, encourages breastfeeding communities and other breastfeeding mothers who have excess breast milk to voluntarily give breast milk to these babies in order to save their lives.

Soerjono Soekanto said that "law as a tool to change society". ${ }^{1}$ With the enactment of Government Regulation of the Republic of Indonesia number 33 of 2012 due to the government's program on exclusive breastfeeding, the need for breast milk has increased because of the awareness of mothers about the importance of breast milk as the main and best food for babies. The regulation of the issue of breastfeeding donors in Article 11 of the Government Regulation makes breastfeeding donation legal in Indonesia. This regulation has at least changed people's thinking about the importance of exclusive breastfeeding and donating breast milk for babies who really need it, so that many people have carried out breast milk donation activities. The existence of breast milk donation activities in the community has made MUI stipulate a fatwa on breast milk donors. The fatwa allows the activity of breast milk donors, thus making breast milk donation no longer a taboo in Indonesia, especially Muslims as the largest religion adhered to by the Indonesian people.

\section{Maslahah's Study of the MUI Fatwa on the Permissibility of Donating Breast Milk}

Maslahah is one of the methods of Ijtihad in Usul fiqh. Maslahah in Arabic means actions

\footnotetext{
period of delivery. Exclusive breastfeeding is over"

${ }^{51}$ Soerjono Soekanto, Pokok-Pokok Sosiologi Hukum, (Jakarta: Rajawali Press, 2008), p. 107.
} 
that encourage goodness. ${ }^{52}$ Anything that is beneficial either in the sense of attracting good or repelling harm. Al-Ghazali explained that mashlahah means something that brings benefits and keeps it away from harm, but by maintaining the goals of syara ' which include maintaining religion, soul, mind, lineage, and property. According to Al-Ghazali, the essence of mashlahah is looking at the syara' law (in establishing the law). ${ }^{53}$

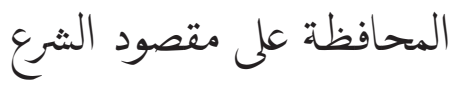

Al-Syatibi interprets mashlahah into two views, namely in terms of the occurrence of mashlahah in reality, and in terms of the dependence of the demands of syara' on mashlahah which is the goal of establishing syara' law. From the several definitions above, it can be concluded that mashlahah which is discussed in the fiqh proposal is not only aimed at fulfilling human needs by following lust and lust. However, the problem is that the goal of syara' (maintaining religion, soul, mind, lineage and property) as a measure and reference, without letting go of the purpose of fulfilling human needs, namely getting benefits and avoiding damage. ${ }^{54}$

The power of maslahah can be seen in terms of the objectives of syara' in establishing laws that are directly or indirectly related to the five main principles of human life, namely to maintain religion, soul, mind, property and offspring. ${ }^{55}$ It can also be seen from the level of compatibility and compatibility of reason with the goals of syara'. In terms of its strength as a proof in establishing the law, there are three kinds of maslahah, namely: mashlahah

${ }^{52}$ Amir Syarifuddin, Ushul Fiqh, (Jakarta: Kencana Perdana Media Group, 2017), Cet.ke-6, Jilid 2, p. 345.

${ }^{53}$ Amir Syarifuddin, Ushul Figh, p. 346.

${ }^{54}$ Amir Syarifuddin, Ushul Figh, p. 347.

${ }^{55}$ Zamzami, "Memeliharaal-Dharuriyah Al-Khamsah Dalam Menetapkan Hukum Pada Tataran Perubahan Sosial”, Jurnal Ilmiah Mizani, Vol. 2, No. 1, 2015, p. 43. dharûriyah, mashlahah hâjiyah and mashlahah tahsiniyah.

1. Mashlahah dharuiriyah is a benefit whose existence is very much needed by human life, meaning that human life will be meaningless if one of the five principles is not fulfilled. (guarding religion, soul, mind, lineage and property)

2. Mashlahah hajizyah is the benefit that the level of human life needs for him does not reach the level of dharûriyah. The form of benefit indirectly aims to fulfill dharûriyah needs. However, it can indirectly go to the dharûriyah level.

3. Mashlahah tahsiniyah is the benefit that the level of human needs for him does not reach the dharûriyah level and does not reach the hâjiya level. However, this need needs to be fulfilled in order to provide perfection in human life. ${ }^{56}$

In terms of harmony and compatibility between reason and the objectives of syara in establishing law (munasib) divided into three types, namely: mashlahah al-mu'tabarah, mashlahah al-mulghah, and mashlahah mursalah.

1. Mashlahah al-Mu'tabrah is mashlahah that is calculated by the shari'a, meaning that there are direct and indirect shari'a instructions. The problem of al-Mu'tabarah is divided into two. First, Munâsib Mu' atsir, that is, there are direct instructions from lawmakers who pay attention to the matter. Second, Munâsib Mulâ'im, namely mashlahah for which there is no direct guidance from the syara', but indirectly existed.

2. Mashlahah al-Mulghah is mashlahah that is rejected, i.e. mashlahah which is considered

56 Susilawati, Nilda. "Stratifikasi Al-Maqasid AlKhamsah Dan Penerapannya Dalam Al-Dharuriyat, AlHajjiyat, Al-Tahsiniyyat", Jurnal Ilmiah Mizani, Vol. 2, No. 1, 2015, p. 41. 
good by the mind, but there are syara' instructions that reject it.

3. Mashlahah Mursalah is what the mind considers good, but there is no shari'a guide that refuses and also takes into account the benefit. $^{57}$

The emergence of the phenomenon of breast milk donors in the community of course also raises pros and cons in the community related to religious issues as a result of these activities. Therefore, MUI as the most competent institution for solving or answering any socioreligious problems that always arise and be faced by the community, and has received full trust from both the community and the government, has issued an attitude related to the phenomenon of breastfeeding donors. This attitude was issued in the MUI Fatwa No. 28 of 2013 concerning Breastfeeding Donors (Irtirdla').

In determining the fatwa, the authors assumed that the spirit carried by the MUI was Ijtihâd istishlâhî. Breast milk donation which aims to help babies who do not get breast milk from their biological mothers for certain reasons, is a humanitarian aid to save human life. As explained in the PP regarding exclusive breastfeeding, babies born to the age of 6 months should only consume breast milk without additional food. Therefore, the need for breast milk donors can be categorized into: maslahah dharuriyat and maslahah hajiyat.

The Indonesian Ulema Council relies on the ability to donate breast milk to nas along with the principles of fiqh with considerations of arrurah and hajjah for the benefit. In the case of breastfeeding donors, maslahah arruriyat occurs when the baby receiving the donor is premature and sick. Breast milk produced by mothers who give birth to premature babies is

${ }^{57}$ Amir Syarifuddin, Ushul Fiqh, p. 348-254. different from breast milk from mothers who give birth to normal babies, both in terms of quality and quantity. Therefore, premature babies will need breast milk donation, because the baby cannot consume anything other than breast milk. This situation makes breast milk donors very much needed by babies in order to survive. This is in line with the purpose of the law of Allah to humans, namely: hifz al-nafs or take care of the soul.

In the case of hajah, breast milk donors are needed by babies who do not receive breast milk from their biological mothers due to several factors, such as: the mother died, the mother's whereabouts were unknown and the baby was discarded. Thus, breast milk donors are needed by babies to meet nutritional needs so that they can grow into quality human beings, healthy minds, and strong bodies. Furthermore, it was also explained that breastfeeding for babies can increase intelligence, so babies can have a higher IQ than babies who drink formula milk. ${ }^{58}$ The need for a breast milk donor in a situation like this is a need for hajah. However, if it is not fulfilled, it can go to the level of dhharuri, namely hifz al-'aql.

Consideration of the benefits contained in the permissibility of breastfeeding donors in the maslahah classification in terms of harmony with syara' law, the ability of breastfeeding donors is included in the maslahah al-Muitabarah. Maslahah al-Mu'tabarah is maslahah taken into account by the Shari'ah in establishing the law directly or indirectly. Seeing the benefits contained in the purpose of donating breast milk, namely saving babies by giving what is their right. So this is in line with what is contained in srah AlBaqarah (2) verse 233 regarding the obligation

${ }^{58}$ Dwi Sunar Prasetyono, Buku Pintar ASI Ekslusif: Pengenalan, Praktik dan Kemanfaatan-Kemanfaatannya, (Yogyakarta: DIVA Press, 2009), cet. ke-1, p. 77-78. 
to breastfeed. Breast milk donors can also be confirmed with the ability to give breast milk not to the biological mother as stated in the letter al-Baqarah (2) paragraph 233. The author argues so, because these two things have the same illat, namely breastfeeding not to the biological mother voluntarily.

In the previous discussion, it has been explained that, although breast milk donation is intended on the basis of dharrurî (hifd nafs dan hifd nasl), but in breast milk donors there are also impacts that can occur. There are three impacts that have been described by the author, namely health, psychological and legal impacts.

\section{Health impact:}

As explained in the discussion chapter, that there are several diseases that can be transmitted through disease. Therefore, it is necessary to have a serological examination or blood test to identify the disease. This examination is carried out in breast milk donation procedures in hospitals and lactation clinics. Performing a serological test procedure is a solution to avoid health impacts on breast milk donors. Avoiding the health impact of donating breast milk, making the purpose of donating breast milk in order to maintain the soul (hifz al-nafs).

\section{Psychology impact:}

The psychological impact that will occur on the donor recipient baby is not having a close inner bond with his biological mother. This happens because the baby does not breastfeed directly on his biological mother. However, in urgent circumstances, such as medical reasons or the mother's breast milk is not possible in quality or quantity, breast milk donors are the best solution than giving children formula milk during the period of exclusive breastfeeding. In the rules of fiqh, "if there are two conflicting harms, then the lighter one is taken". 59

In this case, the harm of the child's inner closeness with his mother is a lesser harm than the safety of the child, both soul and mind. Therefore, it is better to accept donated breast milk than to give children formula milk and breast milk from biological mothers, which is not possible both in quality and quantity.

\section{Legal impact (Islamic law/dairy):}

The legal impact on breastfeeding donors is that the mixing of lineages will have implications for the prohibition of marriage because of the milk sibling. It was explained in the previous discussion that the practice of donating breast milk in Indonesia is different from other countries. The practice of breastfeeding donors in Indonesia emphasizes the clarity of breastfeeding by completing and knowing the identity of the donor and recipient of the donor. Donated breast milk is also not mixed together with other donors' milk, such as breast milk donors in other countries' breast milk banks. Therefore, the mixing of lineages in the practice of breastfeeding donors in Indonesia, which is the pros and cons of breastfeeding donors, will not occur. This is due to the clarity of the origin of the donor's breast milk. Breast milk donors who are so clear about their origins, create a benefit aspect (bifz al-Nasl).

In the fatwa, MUI also pays attention to the opinion of Zainuddin bin Abdul Aziz in the book Fathul Mu'in about unidentified mahram women. It is explained that if there are mixed mahram women and it is difficult to identify, then it is permissible to marry whoever among

${ }^{59}$ Toha Andiko, "Pemberdayaan Qawầid Fiqhiyyah dalam Penyelesaian Masalah-masalah Fikih Siyasah Modern”, Al-'Adalah, Vol. 12, No. 1, 2014. 
them is liked. The opinion used by the MUI as one of these legal considerations can be used as a solution when there is a mix-up of lineages, because breast milk is not identified according to the procedure for breastfeeding donors in Indonesia. The MUI fatwa also explains that the principle of donating breast milk is to help people between humans, which is based on the letter al-Mumtahanah verse 8 .

\section{Conclusion}

The phenomenon of breast milk donation is widely carried out in Indonesia for various reasons. First, the need for breast milk is increasing. This is the impact of the increasing awareness of Indonesian women about the importance of exclusive breastfeeding because of the government's program on exclusive breastfeeding. Medical personnel and providers of medical service facilities are required by the government to provide education to mothers starting from pregnancy check-ups until the end of the exclusive breastfeeding period. Second, there is a legal basis that allows breastfeeding donations to be carried out on conditions that have been written in Government Regulation No. 33 of 2012 concerning exclusive breastfeeding. Third, there is an MUI fatwa that allows breast milk donors. This fatwa can at least be a consideration, especially for Muslims in Indonesia to donate breast milk.

The practice of donating breast milk in Indonesia is different from the practice of donating breast milk in foreign milk banks. Donor breast milk in Indonesia is donated in containers according to the identity of the donor, not mixed in one container like in a breast milk bank. The identity of the donor such as name, address, religion is also completely listed as well as the identity of the baby who is the recipient of the donor. The mother of the recipient of the donor and the mother of the donor also communicated directly. Because of that, the confusion of lineage, as feared by scholars who refuse to donate breast milk, because of the ambiguity of breastfeeding will not happen. The status of an unidentified mahram also does not make marriage unlawful according to the opinion of Zainuddin bin Abdul Aziz in the book of fathul mu'in. Breastfeeding donation in Indonesia has the principle of protecting human benefit and the principle of mutual help among human beings.

According to Ijtihâd istishlâhî, Breastfeeding donation which aims to help babies who do not get breast milk from their biological mothers for certain reasons, is a humanitarian aid to save human life. Therefore, it is legal to donate breast milk. Can be categorized in mashlahah dharuriyat if the baby's mother is sick and the baby is premature or sick, and can also include mashlahah hajiyat if the baby's mother dies, or her whereabouts are unknown.

\section{References}

Abbas, Adil Abd al-Mun'im Abu. Al-Zawaj Wa Al-Alaqât Al-Jinsiyyah Fi Al-Islam, alih bahasa Gazi Said, Jakarta: Al-Mahira, 2008, Cet. ke-2.

Andiko, Toha. "Pemberdayaan Qawâ'id Fiqhiyyah dalam Penyelesaian Masalahmasalah Fikih Siyasah Modern”, Al-'Adalah, Vol. 12, No. 1, 2014.

Anisa, Atika Nur. "Rekontekstualisasi Rada'ah di Era Digital (Studi Donor ASI di Lactashare)", Jurnal Tahkim, Vol. XVII, No. 1, Juni 2021.

Asfuah. Atika Proverawati dan Siti, Buku Ajar Gizi Untuk Kebidanan, Yogyakarta: Numed, 2009, Cet. ke-1.

Fatwa Majelis Ulama Indonesia Nomor 28 Tahun 2013 tentang Seputar Masalah Donor ASI Susu Ibu (IIstirdla'), pdf.

Iqrami, Maratul. "Donasi Bank ASI (Air Susu 
Ibu) di RSUD Dr. Soetomo Surabaya dalam Perspektif Hukum Islam”, Tesis Universitas Islam Negeri Maulna Malik Ibrahim Malang, 2012.

Irwansyah, Dedi. "Praktik Donor ASI di Asosiasi Ibu Menyusui Indonesia (AIMI) dalam Perspektif Hukum Islam”, Tesis Universitas Islam Negeri Syarif Hidayatullah, 2011.

Keputusan Ijtima Ulama Komisi Fatwa SeIndonesia tentang Pedoman Fatwa Majelis Ulama Indonesia, Pdf.

Kusuma, Tyas Pratama Puja dan Dania Gusmi Rahayu. "Sistem Informasi Pengelola Bank ASI Berbasis Website (Studi Kasus: Posyandu Keluarahan Bantarsoka)", Jurnal Pendidikan Informatika, Vol. 5, No. 1, Juni 2021.

Mawardi. "Konsep Radha'ah dalam Fiqih", Jurnal Ilmu Syariah, Vol. 8, No. 1, Juni, 2021.

Munawwir, Ahmad Warson. Al-Munawwir Kamus Bahasa Arab Indonesia, Surabaya: Progresif, 1997

Nasầi, Abî 'Abd al-Rahmân Ahmad Ibn Syi'aib al-. Sunan An-Nasẩi, Beirut: Dar Ihya' al Turath $\mathrm{Al}$ Arabi, t.th.

Nur, Ahmad Nurdin. "Bank ASI dan Implikasi Hukumnya dalan Perkawinan Islam Menurut Wahbah al-Zuhailî dan Yûsuf Qardhâwî,” Tesis Universitas Negeri Sunan Kalijaga Yogyakarta, 2011

Nurliana. "Bank ASI Perspektif Hukum Islam", Jurnal Al-Himayah, Vol. 4, No. 1, Maret 2020.

Prasetyono, Dwi Sunar. Buku Pintar ASI Ekslusif: Pengenalan, Praktik dan Kemanfaatankemanfaatannya, Yogyakarta: DIVA Press, 2009, Cet. ke-1.

Qarâdhâwî, Yûsuf. Hadyûl Islam Fatawî Mu'âshirah, alih bahasa As'ad Yasin, Jakarta: Gema Insani Press, 2006.

Rifa'i dan Zuhri. Terjemahan Khulashah Kifayatul Akhyar, Semarang: Karya Toha Putra, 1978

Sajistâni, Abî Dâwud Sulaiman Ibn al-Asy'as. Sunan Abî Dâwud, Al-Ardan: Dar al-A'lam, 2003.
Sam, Ichwan. Pedoman Penyelenggaraan Organisasi Majelis Ulama Indonesia, Jakarta: MUI Pusat, 2001.

Setianingsih, Rudi Haryono dan Sulis. Manfaat ASI Ekslusif Untuk Buah Hati Anda, Yogyakarta: Goyen Publishing, 2014.

Shodik, Mohammad. "Sosiologi Hukum Islam", Hand Out Fakultas Syari'ah dan Hukum Universitas Islam Negeri Sunan Kalijaga Yogyakarta, 2013.

Sitapoe, Mangku. ASI Eksekutif: Arti Penting Bagi Kehidupan, Jakarta: PT.Indeks, 2013, cet.ke-1.

Soekanto, Soerjono. Pendekatan Sosiologi Terhadap Hukum, Jakarta: Bina Aksara, 2008.

Soekanto, Soerjono. Pokok-pokok Sosiologi Hukum, Jakarta: Rajawali Press, 1988.

Sunar, Prasetyo. Buku Pintar ASI Eksklusif: Pengenalan, Praktik dan Kemanfaatkemanfaatannya, cet.ke-1, Yogyakarta: DIVA Press, 2019.

Susilawati, Nilda. "Stratifikasi Al-Maqasid AlKhamsah Dan Penerapannya Dalam AlDharuriyat, Al-Hajjiyat, Al-Tahsiniyyat", Jurnal Ilmiah Mizani, Vol. 2, No. 1, 2015.

Syarifuddin, Amir. Hukum Perkawinan Islam di Indonesia Antara Fikih Munakahat dan Undang-undang Perkawinan, Cet. ke-1, Jakarta: Kencana, 2006.

Syarifuddin, Amir. Ushul Figh, Jakarta: Kencana Perdana Media Group, 2015, Cet. ke-6, Jilid 2.

Tebba, Sudirman. Sosiologi Hukum Islam, Yogyakarta: UII Press Indonesia, 2013.

Ummah, Siti Rokhmatul. "Memahami Maqashid Asy-Syariah pada Ayat Radha'ah Perspektif Keadilan Gender", Jurnal Ilmiah Ahwal Syakhsiyyah, Vol. 3, No.1, 2021.

Law of the Republic of Indonesia Number 36 Year 2009 concerning Health. Pdf

Zamzami, "Memelihara al-Dharuriyah AlKhamsah Dalam Menetapkan Hukum Pada Tataran Perubahan Sosial”, Jurnal Ilmiah Mizani, Vol. 2, No. 1, 2015. 